\title{
Effects of intermittent feeding regimes on growth performance and economic benefits of Amur catfish (Silurus asotus)
}

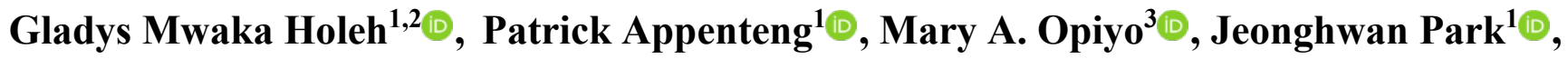 \\ Christopher Lyon Brown' ${ }^{1}$
}

Cite this article as:

Holeh, G.M., Appanteng, P., Opiyo, M.A., Park, J., Brown, C.L. (2020). Effects of intermittent feeding regimes on growth performance and economic benefits of Amur catfish (Silurus asotus). Aquatic Research, 3(3), 167-176. https://doi.org/10.3153/AR20015

\footnotetext{
1. World Fisheries University Pilot Programme Pukyong National University (PKNU), 45 Ongso-ro, Nam-gu, Busan 48513, South Korea

2. Kenya Marine \& Fisheries Research Institute, P.O. Box 81651-80100, Mombasa, Kenya

3. Kenya Marine \& Fisheries Research Institute, National Aquaculture Research Development \& Training Center, P.O. Box 451-10230, Sagana, Kenya
}

ORCID IDs of the author(s): G.M.H. 0000-0002-7103-9485 P.A. 0000-0002-8335-2516 M.A.O. 0000-0001-9660-5888 J.P. 0000-0002-6524-3383 C.L.B. 0000-0002-4578-3593

Submitted: 28.03 .2020

Revision requested: 17.04 .2020

Last revision received: 08.05 .2020

Accepted: 13.05 .2020

Published online: 01.06.2020

Correspondence:

Gladys Mwaka HOLEH

E-mail: holegladys@gmail.com

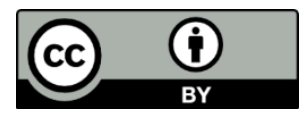

CCopyright 2020 by ScientificWebJournals Available online at http://aquatres.scientificwebjournals.com

\begin{abstract}
A study was conducted to determine the growth performance and economic viability of culturing Amur Catfish (Silurus asotus) using four different feeding regimes: Every-day feeding (EDF), Every two-days feeding (ETDF), Tertian feeding (TF) and Quartan feeding (QF) for 65 days. Twenty fingerlings of sizes between 2-3 grams each were randomly distributed in 12 glass aquaria and assigned to each of the feeding regime in triplicates. Fish were fed on commercial feed (Woosung feed) containing 50\% crude protein. Highest specific growth rates (SGR) $(5.15 \pm 0.06 \%)$ was recorded in EDF with significance differences in all treatments $(P>0.05)$. Feed conversion ratio (FCR) was significantly lower in $\mathrm{TF}(P<0.05)$ while survival rate ranged from $83.33 \%$ to $96.67 \%$ and was not significantly different among the treatments $(P>0.05)$. The length-weight relationship (LWR) analysis indicated that the regression slope $b$ values were not significantly different $(P>0.05)$ among the treatments. Partial enterprise budget analysis of $S$. asotus using different feeding regimes indicated that net returns above total costs were significantly higher in EDF $(P<0.05)$. This shows that every day feeding to satiation is the best feeding regime to be adopted for economic benefits of rearing Amur catfish.
\end{abstract}

Keywords: Amur catfish, Feeding regimes, Alternate feeding, Bio-economy, Growth 


\section{Introduction}

Fish feed is among the most critically important factors influencing the ability of cultured fish to grow profitably in a fish farm (Ereiegha, 2018). Rising feed costs increase production costs, often threatening the economic viability of fish farming. According to Yusuf \& Buhari (2016), some farmers have abandoned production because Catfish prices were not sufficient to offset the cost of production, which had gone up from U\$ 1 to U\$ 1.40 per $\mathrm{kg}$ due to the increase in cost of feed. Earlier studies reported that feeds play a significant role in effective fish production and its profitability, since almost 40$60 \%$ of the total cost for fish production is covered by the feed expenses (Craig and Helfrich (2002), Jamu and Ayinla (2003). Fishmeal costs are particularly volatile, and the use of fishmeal as a source of nutrients for fish farming is environmentally questionable (Hossain et al., 2019). Efforts to decrease the cost of feeds have been done by replacing fish meal with plant proteins (Ergun et al., 2008a,b; Yigit et al., 2010) using different feeding regimes and schedules ( $\mathrm{Wu}$ et al., 1999; Patel and Yakupitiyage 2003; Davies et al., 2006; Goda et al., 2007; Abdel-Tawwab and Ahmad (2009)), optimizing feeding frequencies (Marimuthu et al., 2010) and adjustment of offset timing of supplemental feeding (Brown et al., 2000) but this papers focuses on different feeding regimes to decrease the production cost, without decreasing growth performance of fish.

Amur catfish, also known as Japanese common catfish (Silurus asotus), is a freshwater catfish species from the family Siluridae. It is found in Japan and continental East Asia and is considered as one of the important freshwater species in Korea. The production of Amur catfish in Korea increased from 2,745 tons in 2000 to 5,139 tons in 2017 with a direct sales value of over US\$ 13.7 million (FAO, 2020). Amur catfish is usually reared in water bodies around paddy fields in peninsular and efforts have been made to establish intensive production systems, requiring careful nutritional management at an elevated production cost. According to Jobling (1982), fish fed less frequently consume larger amounts of feed at each feeding time compared to fish fed on a daily basis, contributing to improved growth performance. The rate of feeding to conversion relationship is of significant interest, since insufficient or excessive feeding contributes to decreased feed efficiency and growth, elevated production costs and deteriorating water quality (Shell 1996; Luthada 2012). Research to decrease the production costs of Amur catfish has been done by use of alternative protein-rich ingredients and the use of a fermented by-product of mushroom as a fishmeal replacer (Katya et al., 2014).
Managing feed to improve production and economic returns have been investigated for various fish species including Nile tilapia (Oreochromis niloticus; Bolivar et al., 2006; Opiyo et al., 2014), Gilthead sea bream (Sparus aurata) (Yigit et al., 2012); two band Seabream (Diplodus vulgaris; (Bulut et al., 2014) and African catfish (Clarias gariepinus) Davie et al., 2006). Feeding frequency can strongly affect the ingestion of feed and nutrient absorption hence influencing the growth performance of fish (Marimuthu et al., 2010). This study was designed to assess the effectiveness of intermittent feeding regime on growth performance and yield of Amur catfish ( $\mathrm{Si}$ lurus asotus) by determining the feeding regime that gives the best economic returns of $S$. asotus cultured in tanks.

\section{Material and Methods}

\section{Experimental Design and Diet}

The experiment was done in a completely randomized design in glass aquaria at the Pukyong National University, Busan in the Republic of Korea. A daily and alternate feeding program of one, two and three alternating days was used on Amur catfish fingerlings obtained from the Namsangju fish farm (Namsangju, Republic of Korea). A total of 240 fingerlings with a length of 6-7 $\mathrm{cm}$ and a weight ranging between 2-3 g were acclimated to experimental conditions prior to the start of the feeding trial. Afterwards, 20 fingerlings were distributed in each of 12 aquaria tanks in a semi-recirculating system of 28 litres, containing filtered fresh water with aeration. The aquaria had a constant water flow rate of $2 \mathrm{~L} \mathrm{~min}^{-1}$ and water temperature maintained at $25^{\circ} \mathrm{C}$.

The 12 aquaria were randomly assigned treatments of different feeding regimes of every-day feeding (EDF), every twodays feeding (ETDF), tertian feeding (TF) and quartan feeding $(\mathrm{QF})$ in triplicate treatments. Fish were fed on a commercial sinking catfish feed (pellet size $4 \mathrm{~mm}$ ), obtained from Woosung feed company limited, Republic of South Korea for the first two weeks (Table 1) and later changed to $6 \mathrm{~mm}$ floating pellets from the same company for the remainder of experimental period. The proximate composition of the diet used as prescribed by the manufacturing company is presented in Table 1. Feeding frequencies were monitored according to a feeding schedule "weekly guide" with appropriate days of feeding (Table 2). Fish were fed according to the feeding schedule except for the sampling days after every two weeks. At every feeding day, feeding was done twice a day at $1000 \mathrm{hrs}$ and $1500 \mathrm{hrs}$ to satiation. Feeds of every tank was weighed, broadcasted to the fish, until they stopped eating, then the remaining amount was weighed to get the actual amount of feed eaten. 
Table 1 . Proximate composition of the commercial diet

\begin{tabular}{ll}
\hline Parameter & \% Composition \\
\hline Crude protein & $50.0 \%$ \\
Lipid & $13.0 \%$ \\
Calcium & $2.0 \%$ \\
Crude fibre & $3.0 \%$ \\
Phosphorus & $2.7 \%$ \\
Crude Ash & $17.0 \%$ \\
\hline
\end{tabular}

Table 2. Weekly feeding schedule

\begin{tabular}{lcrcc}
\hline $\begin{array}{r}\text { Day Every-day } \\
\text { feeding } \\
\text { (control, EDF) }\end{array}$ & $\begin{array}{r}\text { Every } \\
\text { two-days } \\
\text { feeding } \\
\text { (ETDF) }\end{array}$ & $\begin{array}{r}\text { Tertian } \\
\text { feeding } \\
\text { (TF) }\end{array}$ & $\begin{array}{c}\text { Quartan } \\
\text { feeding } \\
\text { (QF) }\end{array}$ \\
\hline $\begin{array}{l}\text { Monday } \\
\text { Tuesday }\end{array}$ & $\checkmark$ & $\checkmark$ & $\checkmark$ & $\checkmark$ \\
Wednesday & $\checkmark$ & - & - & - \\
Thursday & $\checkmark$ & $\checkmark$ & - & - \\
Friday & $\checkmark$ & - & $\checkmark$ & - \\
Saturday & $\checkmark$ & - & - & $\checkmark$ \\
Sunday & $\checkmark$ & $\checkmark$ & $\checkmark$ & - \\
Monday & $\checkmark$ & - & - & - \\
& & & & \\
\hline
\end{tabular}

\section{Fish Sampling}

Fish were starved for 24 hours prior to sampling. Total length to the nearest $0.1 \mathrm{~mm}$ was measured using a $30 \mathrm{~cm}$ measuring board, and weight was measured using analytical balance with the precision of $0.01 \mathrm{~g}$. At the end of the trial, fish were counted in every tank to calculate survival. Growth parameters including weight gain, specific growth rate (SGR), Length-weight relationship, survival rate, Feed conversion ratio (FCR), Feed intake and the enterprise budget were calculated using the following formulae respectively.

Specific Growth Rate (SGR) and length-weight relationship were calculated as described by Novoa et al., (1990).

\section{Specific Growth Rate (SGR)}

$=\log _{\mathrm{e}}($ final weight $)-\log _{\mathrm{e}}($ initial weight $) \times 100 \%$ Equation. 1

$$
\text { Culture Days }
$$

A table showing ' $a$ ' and ' $b$ ' values of the length-weight relationship was determined as per the Le Cren law of 1951: $\mathrm{W}=\mathrm{aL}^{\mathrm{b}}$, Where; $\mathrm{W}=$ Weight of fish in grams, $\mathrm{L}=$ the observed total length in $(\mathrm{cm}), a=$ the regression intercept, $b=$ regression slope
\% survival rate (\%SR)

$=\underline{\text { Final number of fish } \times 100 \%} \quad$ Equation. 2

The initial number of fish

\section{Feed Conversion Ratio (FCR)}

$=$ Weight of dry feed fed $(\mathrm{g})$

Equation. 3

Live weight gains of fish $(\mathrm{g})$

\section{Weight Gain (g)}

$=$ Final mean weight $(\mathrm{g})-$ Initial mean Weight $(\mathrm{g})$ Equation. 4

Feed intake (FI)

$=$ Amount fed - wasted feed

Equation. 5

\section{Net fish yield \\ $=$ total weight of fish at harvest-total weight of fish at stocking \\ Equation 6}

\section{Water Quality Management}

Solid wastes were removed in a sedimentation tank at least twice a week for maintenance of water quality. Physicochemical parameters, including temperature and $\mathrm{pH}$ were measured using a $\mathrm{pH}$ meter (YSI model: JA-100), Dissolved Oxygen (DO) was measured two times a day at 10.00 AM and 4.00 PM using a dissolved Oxygen meter, (model No: PDO-519) . Total Ammonia Nitrogen (TAN), and Nitrite-Nitrogen were measured once a week at 9AM using standard laboratory water quality analysis methods according to Boyd \& Tucker (1998).

\section{Profitability Analysis (Economic Feasibility)}

A partial enterprise budget was used to assess the economic performance of the different feeding regimes. The costs considered for the enterprise budget were the Investment costs (Capital), Variable costs (VC) and Fixed costs (FC) according to (Bailey et al 1992). Daily fed fish were considered as the reference point for feeding frequency. The budget was restricted to cost and revenue items influenced by proposed variations in feeding frequency and in determining the possible variations in profit at different feeding frequencies (Opiyo et al., 2014). The cost benefit analysis of the current enterprise was done for each treatment. In the current study, the cost of feeds, fingerlings and other items were estimated as per the existing market prices. The variables included in the enterprise budget were as follows:- 


\section{Gross Returns}

This income was generated from the sale of the Amur catfish.

\section{Variable Cost (VC)}

These are costs that vary with production. They are also called operational costs. They are the cost of fingerlings and feeds that were used in every tank during the culturing period.

\section{Fixed Cost (FC)}

These are costs that were incurred regardless of the level of production of the enterprise. They are the depreciation, interest on the investment, water analysis kits cost, culture facility, permits and licenses, taxes, insurance etc. and any other cost that are not related to the actual enterprise production.

\section{Total Cost (TC)}

It was obtained by adding the Variable costs (VC) and Fixed costs (FC).

\section{Net Return Above Total Costs}

It was obtained by subtracting Fixed costs (FC) from Returns above variable cost.

\section{Yield}

This was the total biomass $(\mathrm{kg})$ obtained from every feeding regime at the end of the culturing period.

\section{Unit Selling Price}

It is the price of selling $1 \mathrm{~kg}$ of the products from every feeding regime

\section{Break-Even Price (BEP) Above Total Cost}

It was obtained by dividing the Total costs over the yield in $\mathrm{kg}$ of every tank/system

\section{Break Even Price Above Variable Cost}

This was calculated by dividing the Variable cost (VC) by total production (Yield). It determines the production cost and the market price that is required to recover variable and fixed cost.

\section{Break Even Yield}

It was obtained by dividing the Total Costs by the Unit selling price.

\section{The Input Expenditure}

- Cost of Amur catfish fingerlings @ US 0.05 \$

- Cost of 50\% crude protein feed @ US 0.5 \$ per kg
- Cost of fish harvested per tank @ US 3 \$ per kg

- Other miscellaneous @ 5 US \$ per tank

\section{Data Analysis}

Data were expressed as means $\pm \mathrm{SE}$. All the trial data were analysed using one-way analysis of variance (ANOVA) to determine difference among groups.. Comparison of means between groups was done by Tukey's HSD test. Statistical differences were considered at $(\mathrm{P}<0.05)$. Data were analysed by SPSS version 20 statistical software (Version 20 for windows).

\section{Results and Discussion}

The overall calculated variables of all results including initial-final length and weight, weight gained, SGR, feed intake, FCR, condition factor and survival rate are summarized in Table 3.

Final mean weight was higher in fish in the EDF regime $(171.74 \pm 10.09 \mathrm{~g})$ and lowest in QF. The highest weight gain was observed in the EDF $(165.70 \pm 9.98 \mathrm{~g})$ followed by ETDF $(136.46 \pm 4.92 \mathrm{~g})$. SGR over the culture period decreased with an increase in feeding frequency. The highest was on EDF $\left(5.15 \pm 0.06 \%\right.$ day $\left.^{-1}\right)$ while the lowest SGR was in QF with a value of $4.24 \pm 0.12 \%$ day $^{-1}$. There were significant differences among the treatments for final body weight, weight gain and SGR $(P<0.05)$. With regard to feed intake, EDF consumed the highest amount of feed $(2813 \mathrm{~g})$ for the sixtyfive days while QF consumed the least amount of feeds $(656 \mathrm{~g})$. On the other hand, FCR increased with the decrease in feeding frequencies except at TF where the FCR value was 0.65 . The lowest FCR was observed in QF and the highest FCR was observed in EDF. With regard to feed utilization, there was a significant difference $(\mathrm{P}<0.05)$ in the FCR of the different feeding regimes. Due to feeding sinking pellets and changing to floating pellets in the third week of experiment, it was observed that less amount of feed was consumed during the first two days of the third week after changing sinking to floating pellets to the fish. Additionally, fish were using more effort to reach feeds, which was unusual compared to feeding on sinking pellets in the first two weeks.

In this study, the highest survival rate was observed in ETDF $(96.67 \pm 3.33 \%)$ followed by EDF having $95.00 \pm 2.87 \%$. The survival rates among the treatments were not significantly different $(\mathrm{P}>0.05)$. Length-weight relationship of the fish indicated highest $b$-value for QF $(2.76 \pm 0.29)$ followed by EDF. The (b) values were however not significantly different in all treatments $(\mathrm{P}>0.05)$. The condition factors of fish in all the feeding regimes ranged from 0.70 to 0.73 and were not affected by the feeding regime $(\mathrm{P}>0.05)$. 


\section{Water Quality Parameters}

Water temperature was kept at $25^{\circ} \mathrm{C}$ in the entire culture period in all the treatments. Higher dissolved oxygen was observed in QF and was increasing with the decrease in feeding frequency (Table 4). Dissolved Oxygen values were significantly affected by the feeding regimes $(\mathrm{P}>0.05)$. High Total ammonia nitrogen (TAN) and Nitrite-Nitrogen $\left(\mathrm{NO}_{2}-\mathrm{N}\right)$ levels were observed in EDF which was receiving feed daily and were at $0.86 \pm 0.22 \mathrm{mg} \mathrm{L}^{-1}$ and $0.73 \pm 0.22 \mathrm{mg} \mathrm{L}^{-1}$ respectively. However, the TAN levels were not significantly different $(\mathrm{P}>0.05)$ in all the feeding regimes.

Table 3. Growth performance of amur catfish (Silurus asotus) on different feeding regimes for 65 days

\begin{tabular}{llllll}
\hline Variables & \multicolumn{5}{c}{ Treatments } \\
\cline { 2 - 6 } & $\begin{array}{l}\text { Every-day } \\
\text { feeding (EDF) }\end{array}$ & $\begin{array}{l}\text { Every two-day } \\
\text { Feeding (ETDF) }\end{array}$ & $\begin{array}{l}\text { Tertian feeding } \\
\text { (TF) }\end{array}$ & $\begin{array}{l}\text { Quartan feeding } \\
(\mathbf{Q F})\end{array}$ & P-value \\
\hline Initial Length (cm) & $8.10 \pm 0.00^{\mathrm{a}}$ & $7.97 \pm 0.14^{\mathrm{a}}$ & $8.02 \pm 0.22^{\mathrm{a}}$ & $7.67 \pm 0.12^{\mathrm{a}}$ & 0.23 \\
Final Length (cm) & $28.75 \pm 0.45^{\mathrm{a}}$ & $27.05 \pm 0.39^{\mathrm{a}}$ & $24.60 \pm 0.69^{\mathrm{b}}$ & $23.14 \pm 0.43^{\mathrm{b}}$ & 0.00 \\
Initial Weight (g) & $6.04 \pm 0.11^{\mathrm{a}}$ & $5.28 \pm 0.32^{\mathrm{a}}$ & $5.46 \pm 0.66^{\mathrm{a}}$ & $5.55 \pm 0.31^{\mathrm{a}}$ & 0.61 \\
Total Initial Weight (TIW) (g) & $120.75 \pm 2.19^{\mathrm{a}}$ & $105.65 \pm 6.40^{\mathrm{a}}$ & $109.13 \pm 13.15^{\mathrm{a}}$ & $111.07 \pm 6.11^{\mathrm{a}}$ & 0.60 \\
Final Weight (g) & $171.74 \pm 10.09^{\mathrm{a}}$ & $141.75 \pm 10.09^{\mathrm{b}}$ & $104.50 \pm 10.09^{\mathrm{c}}$ & $87.65 \pm 5.62^{\mathrm{d}}$ & 0.00 \\
Total Final Weight (TFW) (g) & $3307.30 \pm 84.50^{\mathrm{a}}$ & $2688.30 \pm 41.3^{\mathrm{b}}$ & $1789.70 \pm 77.40^{\mathrm{c}}$ & $1369.70 \pm 60.7^{\mathrm{d}}$ & 0.00 \\
WG (\%) & $2740.70 \pm 1.16^{\mathrm{a}}$ & $2611.50 \pm 2.38^{\mathrm{a}}$ & $1834.10 \pm 1.15^{\mathrm{b}}$ & $1486.20 \pm 1.25^{\mathrm{b}}$ & 0.00 \\
SGR & $5.15 \pm 0.06^{\mathrm{a}}$ & $5.07 \pm 0.14^{\mathrm{a}}$ & $4.55 \pm 0.09^{\mathrm{b}}$ & $4.24 \pm 0.12^{\mathrm{b}}$ & 0.00 \\
Feed Intake (g) & $2813.30 \pm 52.07^{\mathrm{a}}$ & $1551.50 \pm 139.55^{\mathrm{b}}$ & $1099.90 \pm 32.97^{\mathrm{c}}$ & $656.51 \pm 9.07^{\mathrm{d}}$ & 0.00 \\
FCR & $0.88 \pm 0.01^{\mathrm{a}}$ & $0.60 \pm 0.01^{\mathrm{b}}$ & $0.65 \pm 0.01^{\mathrm{bc}}$ & $0.52 \pm 0.03^{\mathrm{a}}$ & 0.00 \\
Survival Rate (\%) & $95.00 \pm 2.87^{\mathrm{a}}$ & $96.67 \pm 3.33^{\mathrm{a}}$ & $86.67 \pm 6.01^{\mathrm{a}}$ & $83.33 \pm 6.01^{\mathrm{a}}$ & 0.22 \\
$\boldsymbol{b}$-value & $2.65 \pm 0.06^{\mathrm{a}}$ & $2.62 \pm 0.20^{\mathrm{a}}$ & $2.64 \pm 0.15^{\mathrm{a}}$ & $2.76 \pm 0.29^{\mathrm{a}}$ & 0.96 \\
Condition factor (K) & $0.72 \pm 0.01^{\mathrm{a}}$ & $0.73 \pm 0.02^{\mathrm{a}}$ & $0.70 \pm 0.01^{\mathrm{a}}$ & $0.70 \pm 0.01^{\mathrm{a}}$ & 0.21 \\
\hline
\end{tabular}

The values are articulated as Mean \pm Standard Error (SE). Values in the same row with same superscript letters are not significantly different $(\mathrm{P}>0.05)$

Table 4. Water quality parameters of Amur catfish (Silurus asotus) on different feeding regimes for 65 days

\begin{tabular}{|c|c|c|c|c|c|}
\hline \multirow[t]{2}{*}{ Variable } & \multicolumn{5}{|l|}{ Treatments } \\
\hline & $\begin{array}{l}\text { Every-day feeding } \\
\text { Control (EDF) }\end{array}$ & $\begin{array}{l}\text { Every two-day } \\
\text { feeding (ETDF) }\end{array}$ & $\begin{array}{l}\text { Tertian feeding } \\
\text { (TF) }\end{array}$ & $\begin{array}{l}\text { Quartan feeding } \\
\text { (QF) }\end{array}$ & P-Value \\
\hline Temperature $\left({ }^{\circ} \mathrm{C}\right)$ & $24.00 \pm 1.06^{\mathrm{a}}$ & $24.00 \pm 1.06^{\mathrm{a}}$ & $24.00 \pm 1.06^{\mathrm{a}}$ & $24.00 \pm 1.06^{\mathrm{a}}$ & 0.07 \\
\hline Dissolved Oxygen $\left(\mathrm{mg} \mathrm{L}^{-1}\right)$ & $5.86 \pm 0.18^{\mathrm{b}}$ & $6.14 \pm 0.17^{\mathrm{ab}}$ & $6.40 \pm 0.18^{\mathrm{ab}}$ & $6.60 \pm 0.18^{\mathrm{a}}$ & 0.04 \\
\hline pH & $6.87 \pm 0.17^{\mathrm{a}}$ & $6.86 \pm 0.20^{\mathrm{a}}$ & $6.45 \pm 0.11^{\mathrm{a}}$ & $6.36 \pm 0.18^{\mathrm{a}}$ & 0.07 \\
\hline $\mathrm{NO}_{2}-\mathrm{N}\left(\mathrm{mg} \mathrm{L}^{-1}\right)$ & $0.73 \pm 0.22^{\mathrm{a}}$ & $0.53 \pm 0.15^{\mathrm{a}}$ & $0.48 \pm 0.14^{\mathrm{a}}$ & $0.46 \pm 0.14^{\mathrm{a}}$ & 0.63 \\
\hline TAN $\left(\mathrm{mg} \mathrm{L}^{-1}\right)$ & $0.86 \pm 0.25^{\mathrm{a}}$ & $0.73 \pm 0.22^{\mathrm{a}}$ & $0.65 \pm 0.22^{\mathrm{a}}$ & $0.64 \pm 0.38^{\mathrm{a}}$ & 0.87 \\
\hline
\end{tabular}




\section{Enterprise Budget Analysis of Amur Catfish}

The economic performance of the different feeding schedules is summarized in table 5 below. There was a significant difference between the net returns above variable cost (VC) for all treatments $(\mathrm{P}<0.05)$ and the returns were decreasing with increasing feeding frequency. The cost of feed increased with an increase in feed frequency. The cost of feed was significantly higher in EDF with an equivalent of 1.11 USD. For all treatments, the returns above variable costs and net returns above total costs were significantly higher in EDF $(\mathrm{P}<0.05)$ in comparison to the rest of the treatments. However, none of the treatments had a negative net return on total costs and the break-even price above total variable costs was below the unit-selling price of each fish in all the treatments.

Table 5. Partial enterprise budget of Amur catfish (Silurus asotus) on different feeding regimes (US\$)

\begin{tabular}{lllll}
\hline Variable & \multicolumn{4}{c}{ Treatment } \\
\cline { 2 - 5 } & $\begin{array}{l}\text { Every-day } \\
\text { feeding (EDF) }\end{array}$ & $\begin{array}{l}\text { Every two-day } \\
\text { feeding } \\
\text { (ETDF) }\end{array}$ & $\begin{array}{l}\text { Tertian } \\
\text { feeding (TF) }\end{array}$ & $\begin{array}{l}\text { Quartan } \\
\text { feeding (QF) }\end{array}$ \\
\hline Gross Revenue & $9.92 \pm 0.25^{\mathrm{a}}$ & $8.07 \pm 0.12^{\mathrm{b}}$ & $5.37 \pm 0.23^{\mathrm{c}}$ & $4.11 \pm 0.18^{\mathrm{d}}$ \\
Variable Cost (VC) & $2.11 \pm 0.03^{\mathrm{a}}$ & $1.78 \pm 0.02^{\mathrm{b}}$ & $1.55 \pm 0.02^{\mathrm{c}}$ & $1.33 \pm 0.00^{\mathrm{d}}$ \\
Returns above VC & $7.81 \pm 0.23^{\mathrm{a}}$ & $6.29 \pm 0.10^{\mathrm{b}}$ & $3.82 \pm 0.21^{\mathrm{c}}$ & $2.78 \pm 0.18^{\mathrm{d}}$ \\
Fixed Cost (FC) & $0.30 \pm 0.00^{\mathrm{a}}$ & $0.30 \pm 0.00^{\mathrm{a}}$ & $0.30 \pm 0.00^{\mathrm{a}}$ & $0.30 \pm 0.00^{\mathrm{a}}$ \\
Total Cost (TC) & $2.41 \pm 0.03^{\mathrm{a}}$ & $2.08 \pm 0.02^{\mathrm{b}}$ & $1.85 \pm 0.02^{\mathrm{c}}$ & $1.63 \pm 0.00^{\mathrm{d}}$ \\
Net returns above TC & $7.51 \pm 0.23^{\mathrm{a}}$ & $5.99 \pm 0.10^{\mathrm{b}}$ & $3.52 \pm 0.21^{\mathrm{c}}$ & $2.48 \pm 0.18^{\mathrm{d}}$ \\
Yield (Kg/pond) & $3.31 \pm 0.08^{\mathrm{a}}$ & $2.69 \pm 0.04^{\mathrm{b}}$ & $1.79 \pm 0.08^{\mathrm{c}}$ & $1.37 \pm 0.06^{\mathrm{d}}$ \\
Unit selling price & $3.00 \pm 0.0^{\mathrm{a}}$ & $3.00 \pm 0.00^{\mathrm{a}}$ & $3.00 \pm 0.00^{\mathrm{a}}$ & $3.00 \pm 0.00^{\mathrm{a}}$ \\
Amount of feed consumed (kg) & $2.22 \pm 0.05^{\mathrm{a}}$ & $1.55 \pm 0.04^{\mathrm{b}}$ & $1.11 \pm 0.03^{\mathrm{c}}$ & $0.65 \pm 0.01^{\mathrm{d}}$ \\
Cost of Feeds & $1.11 \pm 0.03$ & $0.78 \pm 0.02$ & $0.55 \pm 0.02$ & $0.33 \pm 0.01$ \\
Break Even Price of total cost & $0.73 \pm 0.01^{\mathrm{c}}$ & $0.77 \pm 0.01^{\mathrm{c}}$ & $1.04 \pm 0.04^{\mathrm{b}}$ & $1.19 \pm 0.05^{\mathrm{a}}$ \\
Break Even Price of Variable Cost & $0.64 \pm 0.01^{\mathrm{b}}$ & $0.66 \pm 0.00^{\mathrm{b}}$ & $0.87 \pm 0.03^{\mathrm{a}}$ & $0.97 \pm 0.04^{\mathrm{a}}$ \\
Break Even Yield (kg) of TC & $0.80 \pm 0.01^{\mathrm{a}}$ & $0.69 \pm 0.01^{\mathrm{b}}$ & $0.62 \pm 0.01^{\mathrm{c}}$ & $0.54 \pm 0.00^{\mathrm{d}}$ \\
\hline
\end{tabular}

*Values are articulated as mean \pm SE. Values in the same row with the same superscript letters are not significantly different $(\mathrm{P}>0.05)$.

\section{Growth Parameters}

This study indicates that feeding frequency has a substantial impact on fish growth. Fish that were fed daily to satiation had a high weight gain and high SGR. The high growth performance acquired by the fish fed daily was because of the high amount of feed consumed daily by the fish and were efficiently converted to flesh (Verreth \& Eding, 1993). Similarly, better growth rate and food efficiency have been reported for African catfish (C. gariepinus) fed twice per day, (Marimuthu et al., 2010) and catfish (Heterobranchus longifilis) fed twice per day (Davies et al., 2006) which exhibited higher weight gain, SGR and average final weight in comparison to fish fed once per day. Ali and Jouncey (2004) also observed high growth rate on $C$. gariepinus fed daily $(\mathrm{P}<0.05)$.

Other studies have reported no significant difference in SGR of fish fed daily and those fed alternatively (Schnaittacher et al., 2005; Cho et al., 2007). The results of this study are similar to the findings of Biswal et al., (2006) and Opiyo et al. (2014) which reported high growth rate in Indian major carps
(Catla catla) and Nile tilapia (Oreochromis niloticus) fed daily, respectively. In a different study, no significant difference were observed in the mean weight gain, daily weight gain, survival rates except on the amount of feeds used in Nile tilapia (Bolivar et al., 2006), although the consumption of pond plankton was an uncontrolled variable in that study. It is also observed that fish fed less frequently consumed a large amount of feed at once compared to the fish fed daily during each meal, resulting in high growth performance.

High FCR was recorded in fish that were daily fed (EDF) followed by tertian fed (TF) fish. This was similar to findings of Salama, (2008) whose experiment on Sea bass (Lates calcarifer) fed twice daily which recorded a FCR of 2.43.The results are an indication that feed consumption and feed conversion efficiency was subjective to the feeding frequency. Fish fed every two days did not utilize the feed efficiently compared to fish on quartan feeding, , indicating that fish on quartan feeding had better feed conversion to flesh with an FCR of 0.52. However, Opiyo et al. (2014) observed a low 
FCR of 1.04 in fish that were fed after two-days which was contradicting the results of the present study whose quartan feeding regime had the lowest FCR. The relationship between the feeding frequency and the rate of conversion is very important in fish culture. When fish are insufficiently fed or excessively fed, their feed utilization efficiency may decrease, causing an increase in production cost and water quality deterioration (Luthada, 2012). For these and possibly other reasons, studies comparing various feeding schedules often lead to the recommendation that moderate feeding is commercially optimal (Brown et al., 2004).

In this study, feeding frequency affected the survival rate of Silurus asotus. Alternate every two-day feeding treatment had the highest survival rate percentage followed by the daily feeding treatment. This observation contradicts that of Opiyo et al., (2014) which showed a significantly high survival rate of daily fed fish but in line with the study of Bolivar, Jimenez \& Brown, (2006) which recorded a mean survival rate of 63.42 and 55.35 for alternatively fed samples and daily fed samples respectively.In the current study, the lowest survival rate for the whole period was $83 \%$ in fish on quartan feeding and could be attributed to high cannibalistic nature of Silurus asotus when left unfed for more than one day.

A decrease in growth performance was observed with a decrease in feeding frequency. Highest decrease was however observed in fish fed daily. According to Shell (1996), fish fed excessively results in poor growth due to detrimental effects of uneaten food decaying in water leading to poor water quality (Abou-Zied, 2015). Additionaly, regular fish feeding in controlled conditions increases stress in fish due to the vigorous movement of fish, which leads to loss of energy (Anderson et al., 1996).

The mean $b$ value of the quartan feeding was higher (2.76) compared to the other regimes with no significant difference. This could be an indication of fish having more girth or more fat as it grows longer, and spends extra energy for growth and reproduction (Anderson et al., 1996). The quartan feeding treatment had fish considered healthier because of $b$-value of 2.76 - almost 3, the standard exponential b-value of most fish species; a parameter, which could also be used to deduce the health condition of fish (Froese 2006). The low b value of the daily fed fish could be because of high stocking density, which might have led to stressful environment in the culture unit. The b-values recorded in this study $(2.62-2.76)$ are similar to that of Skipjack tuna (Katsuwonus pelamis) observed by Jin et al. (2015), who further suggested that the b values should mainly be used for assessing growth rates due to their high rates of increase during the growth stage.
All condition factors in the present study were less than 1 , the standard figure for condition factor. When $\mathrm{K}$ is 1 , the fish is considered to be healthy but less than that shows an unhealthy condition (Ighwela et al., 2011). For this reason, all the feeding regimes depicted an unhealthy condition of fish. This could be as a result of the high stocking density which could possibly led to increasing stress levels of the fish in all the feeding regimes.

\section{Enterprise Budget}

In the present study, holding tanks, water and power were kept constant and were not considered in the enterprise budget analysis. Positive net returns were recorded in all the feeding regimes.. This was in line with the result of Opiyo et al., (2014) who observed the profitability of Nile tilapia on alternate feeding regimes in fertilized earthen ponds.. Positive returns above variable costs indicate that it is profitable to operate the enterprise in the short run (Engle and Neira, 2005) and negative net returns indicate that the enterprise is not profitable for the long term (Stone et al., 2008). Engle (1977) observed a negative net return in every acre of land on Arkansas catfish production budget and this was because of high cost of labour in paying the overall manager and supervisors.

The break-even price above the variable cost of the present was 0.64 US $\$$ per $\mathrm{kg}$ for the fish fed on a daily basis. This indicates that Amur catfish production can be profitable as long as the price is above 0.6 US \$. Feeding fish daily was the utmost profitable compared to other feeding frequency due to the fast and high growth performance of the fish because of high feed consumption leading to a high weight gain? The cost of feed for the daily fed fish was higher (1.11 US \$) compared to the other feeding regimes. The high cost of feed observed in fish fed daily could be because of the high consumption of feed during the culture period, unlike the other feeding regimes.

\section{Conclusion}

This study built on the fish growth performance and the utilization of feed for Amur catfish (S. asotus) to be fed to satiation every day for optimum growth, survival, and better economic returns. Feeding fish to satiation twice every day was more profitable than other feeding regimes though quartan feeding had reduced labour and production costs.

\section{Compliance with Ethical Standard}

Conflict of interests: The authors declare that for this article they have no actual, potential or perceived conflict of interests. 
Ethics committee approval: All applicable international, national, and/or institutional guidelines for the care and use of animals were followed by the authors during the study.

Funding disclosure: This study is a part of first authors Msc. Thesis which was supported by the World Fisheries University-Pilot Program at the Pukyong National University, Aquaculture laboratory.

Acknowledgments: We would like to appreciate Prof.Christopher Lyon Brown of the World Fisheries University for editing and proofreading this work.

\section{References}

Abdel-Tawwab, M., Ahmad, M.H. (2009). Effect of dietary protein regime during the growing period on growth performance, feed utilization and whole-body chemical composition of Nile Tilapia, Oreochromis niloticus (L.). Aquaculture Research, 40(13), 1532-1537.

https://doi.org/10.1111/j.1365-2109.02254.x

Abou-Zied, R. M. (2015). Effect of diet extruded type on growth performance, feed utilization and economic efficiency of Nile tilapia in commercial farms. Egyptian Journal of Nutrition and Feeds, 18(1), 143-150.

Ali, M. Z., Jauncey, K. (2004). Evaluation of mixed feeding schedules with respect to compensatory growth and body composition in African catfish Clarias gariepinus. Aquaculture Nutrition, 10(1). 1365-2095.

https://doi.org/10.1046/j.1365-2095.2003.00278.x

Anderson, R., Neumann, R. M. (1996). Length, Weight and Associated Structural Indices. In: B.R.. Murphy, \& D.W. Willis, (Eds), Fisheries techniques, 2nd edition. American Fisheries Society, Bethesda, Maryland 447-482.

Bailey, D.S., Hargreaves, J.A., Rakocy, J.E. (1992). Enterprise budget analysis of three stocking densities of caged Florida red tilapia. Proc. Gulf Carib. Fish.

Biswal, G., Jena, J.K., Singh, S.K., Muduli, H.K. (2006). Effect of feeding frequency on growth, survival and feed utilization in fingerlings of Catla catla (Hamilton), Labeo rohita (Hamilton) and Cirrhinus mrigala (Hamilton) in outdoor rearing systems. Aquaculture Research, 37(5), 510-514. https://doi.org/10.1111/j.1365-2109.2006.01457.x

Bolivar, R.J., Brown, C.L. (2006). Alternate day feeding strategy for nile tilapia growth out in the phillipines: marginal cost revenue analysis 1. North American Journal of Aquaculture, 68, 192-197.

https://doi.org/10.1577/A05-012.1

Boyd, C.E., Tucker, C.S. (1998). Pond Aquaculture Water Quality Management. Kluwer Academic Publishers, Boston, Massachusetts, USA.

https://doi.org/10.1007/978-1-4615-5407-3

Brown, C.L., Bolivar, R.B., Jimenez, E.B. (2000). Timing of the onset of supplemental feeeding of Nile Tilapia (Oreochromis niloticus) in ponds. In: Fitzsimmons K, Filho JC, editors. Tilapia Aquaculture in the 21st Century. Proceedings from the 5th Int'l Symposium on Tilapia Aquaculture. Brazil, Rio de Janeiro, 2000. p. 682, 237-240.

Brown, C.L., Bolivar, B., Jimenez, E.B. (2004). Philippine studies support moderate feeding in tilapia. Global Aquaculture Alliance Advocate 7,4 p70.

Bulut M., Yigit M., Ergun S., Kesbic O.S., Acar U., Gultepe N., Karga M., Yilmaz S., Guroy D. (2014). Evaluation of dietary protein and lipid requirements of two banded seabream Diplodus vulgaris cultured in a Recirculating. Aquaculture International, 22, 965-973.

https://doi.org/10.1007/s10499-013-9720-z

Cho, S.H., Lim, Y.S., Lee, J.H., Lee, J.K., Park, S., Lee, S.M. (2007). Effects of feeding rate and feeding frequency on survival, growth, and body composition of ayu postlarvae Plecoglossus altivelis. Journal of the World Aquaculture Society, 34 (1), 81-91.

https://doi.org/10.1111/j.1749-7345.2003.tb00042.x

Craig, S., Helfrich, L.A. (2002). Understanding Fish Nutrition, Feeds and Feeding, Cooperative Extension Service, publication 420-256. Virginia State University, USA.

Davies, O.A., Inko-Tariah. M.B., Amachree, D. (2006). Growth response and survival of Heterobranchus longifilis fingerlings fed at different feeding frequencies. African Journal of Biotechnology, 5(9), 778-787.

El-sayed, A.F., Malcolm, W. Dickson., Gamal, O. El-Naggar. (2015). Value chain analysis of the aquaculture feed sector in Egypt. Aquaculture, 437, 92-101.

https://doi.org/10.1016/j.aquaculture.2014.11.033

Engle, C.R. (1977). Catfish production budgets. Cooperative extension program, University of Arkansas at Pine Bluff, 
United states Department of Agriculture, and County Governments cooperating. MP 466-PD-6-07N.

Engle, C., Neira, I. (2005). Tilapia farm Business management and Economics: a train manual. Aquaculture Collaborative Research Program (CRSP), United States Agency for International Development (USAID), Pine Bluff. p. 41.

Ereiegha, Ochuko. Joshua., Ekokotu, Peterson. Adogbeji. (2017). Factors affecting feed intake in cultured fish aspecies, A review. Animal Research International, 14(2), 2697-2709.

Ergun, S., Yigit, M., Turker, A., Harmantepe, F.B. (2008a). Incorporation of soybean meal and hazelnut meal in diets for Black Sea Turbot (Scophthaimus maeoticus). Journal of Aquaculture-Bamidgeh, 60, 27-36.

Ergun, S., Yigit, M., Turker, A., Harmantepe, F.B., (2008b). Partial replacement of Fishmeal by Defatted Soybean Meal in Diets for Black Sea Turbot Psetta maeoti-ca Growth and Nutrient Utilization in Winter. Israel Jour-nal of Aquaculture-Bamidgeh, 60, 177-184.

FAO (2020). FAO-Fisheries and Aquaculture Information and Statistics

http://www.fao.org/fishery/statistics/global-production/query/en (Accessed 07.05.2019).

Froese, R. (2006). Cube law, Condition factor and weightlength relationship: History, meta-analysis and recommendations. Journal of Applied Ichthyology, 22(4), 241-253.

https://doi.org/10.1111/j.1439-0426.2006.00805.x

Goda, A.M.A-S., Wafa, M.E., El-Haroun, E.R., Chowdhury, M.A.K. (2007b). Growth performance and feed utilization of Nile tilapia Oreochromis niloticus (Linnaeus, 1758) and tilapia galilae Sarotherodon galilaeus (Linnaeus, 1758) fingerlings fed plant pro-tein based diets. Aquaculture Research, 38(8), 827-837.

https://doi.org/10.1111/j.1365-2109.2007.01731.x

Hossain, M.M., Chakraborty, S.C., Brown, C.L. (2019). Evaluation of sunflower cake as a replacement for fishmeal in Nile tilapia (Oreochromis niloticus) production. Australian Journal of Science and Technology 2(2), 90-98.

Jamu, D.M. Ayinla, O.A. (2003). Potential for the development of aquaculture in Africa. Naga, 26(3), 9-13,
Jin, S., Yan, X., Zhang, H., Fan, W. (2015). Weight-Length relationship and fulton's condition factors of skipjack tuna (Katsuwonas pelamis) in the Western and Central Pacific Ocean. PeerJ, 12(3), e758.

https://doi.org/10.7717/peerj.758

Jobling, M. (1982). Some observations on the effects of feeding frequency on the food intake and growth of plaice, Pleuronectes platesa L. Journal of Fish Biology, 20(4), 431-444. https://doi.org/10.1111/j.1095-8649.1982.tb03936.x

Katya, K., Yun, Y.H., Lee, J.Y., Yoo, G., Bai, S.C. (2014). Evaluation of the efficacy of fermented by-product of mushroom, pleurotus ostreatus, as a fish meal replacer in juvenile Amur Catfish, Silurus asotus: effects on growth, serological characteristics and immune responses. Asian-Australasian Journal of Animal Sciences, 27(10), 1478-1486.

https://doi.org/10.5713/ajas.2014.14038

Ighwela, K.A., Ahmed, A.B., Abol-Munafi, A.B. (2011). Condition factor as an indicator of growth and feeding intensity of Nile tilapia fingerlings (Oreochromis niloticus) feed on different levels of maltose. American-Eurasian Journal of Agricultural and Environmental Science, 11(4), 559-563.

Luthada, R.W. (2012). Effect of dietary protein level, feeding frequency and amount of food offered on growth and gastric evacuation of Oreochromis mosambicus fry. Doctoral dissertation, Department of Zoology, University of Zululand, South Africa.

Marimuthu, K., Cheen, A.C., Muralikrishnan, S., Kumar, D. (2010). Effect of different feeding frequency on the growth and survival of African catfish (Clarias gariepinus) fingerlings. Advances in Environmental Biology, 4(2), 187193.

Novoa-Olvera, M.A., Campos, G. S., Sabido, G.M., Martinez Palacios, C.A. (1990). The use of alfalfa leaf protein concentrates as a protein source in diets for tilapia (Oreochromis mossambicus). Aquaculture, 90(3-4), 291-302. https://doi.org/10.1016/0044-8486(90)90253-J

Opiyo, M.A, Munguti, J.M., Ogello, E.O., Karisa, H.C. (2014). Growth response, survival and profitability of nile tilapia (Oreochromis niloticus) fed at different feeding frequencies in fertilized earthen ponds. International Journal of Science and Research, 3(9), 2319-7064. 
Patel, B.A., Yakupitiyage, A. (2003). Mixed feeding schedules in semi-intensive pond culture of Nile tilapia, Oreo-chromis niloticus $\mathrm{L}$. is it necessary to have two diets of dif-ferent protein content? Aquaculture Research, 34, 1343-1352.

https://doi.org/10.1046/j.1365-2109.2003.00957.x

Salama, A.J. (2008). Effects of different feeding frequency on the growth, survival and feed conversion ratio of the Asian sea bass, Lates calcarifer juveniles reared under hypersaline seawater of the Red Sea. Aquaculture Research, 39(6), 561567.

https://doi.org/10.1111/j.1365-2109.2007.01890.x

Schnaittacher, G., King, V.W., Berlinsky, D.L. (2005). The effects of feeding frequency on growth of juvenile Atlantic halibut, Hippoglossus hippoglossus L. Aquaculture Research, 36(4), 370-377.

https://doi.org/10.1111/j.1365-2109.2005.01218.x

Shell, E.W. (1996). Proceedings of the FAO World Symposium on Warm water pond fish culture. FAO Fisheries reports No. 44 , Vol.3

Stone, H., Sidel, J.L., Oliver, S., Woolsey, A. (2008). Sensory Evaluation by quantitative descriptive analysis, pp.2334.

https://doi.org/10.1002/9780470385036.ch1c
Verreth, J.A., Eding, E. (1993). European farming industry of African catfish (Clarias gariepinus): Facts and figures. Aquaculture Europe Magazine, 18(2), 6-13.

Wu, Y.V., Tudor, K.W., Brown, P.B. (1999). Substitution of plant proteins and bone meal for fish meal in diets of Nile tilapia. North American Journal of Aquaculture, 6, 58-63. https://doi.org/10.1577/1548-8454(1999)061<0058:SOP$\mathrm{POM}>2.0 . \mathrm{CO} ; 2$

Yigit, M., Ergun, S., Turker, A., Harmantepe, F.B., Adnan, E. (2010). Evaluation of soybean meal as a protein source and its effects on growth and nitrogen utilization of Black Sea Turbot (Psetta maeotica) juveniles. Journal of Marine Science and Technology-Taiwan, 18, 682-688.

Yigit, M., Bulut, M., Ergun, S., Guroy, D., Karga, M., Kesbic, O.S., Yilmaz, S., Acar, U., Guroy, B., (2012). Utilization of corn gluten meal as a protein source in diets for gilthead sea bream (Sparus aurata L.) juveniles. Journal of FisheriesSciences.com, 6, 63-73. https://doi.org/10.3153/jfscom.2012008

Yusuf, V.A., Buhari, S. (2016). Why Prices of Fish Feeds Go up. Nigeria: Daily Trust. https://allafrica.com/stories/201606160661.html (Accessed 07.05.2019). 